\title{
The client's behaviour towards the bank in Algeria (Public Bank Vs Foreign Bank)
}

\author{
http://doi.org/10.21272/fmir.4(1).100-108.2020
}

\section{Zerigui Khadidja}

Dr, Lecturer "B", Department of Management Sciences, University of Oran2 Mohamed Ben Ahmed, Algeria

\begin{abstract}
This paper summarizes the arguments and counterarguments within the scientific discussion regarding the behavioral aspects of customer choice of state or foreign bank banking services. The purpose of the study is to study and analyze the behavior of customers when choosing a bank category (state or foreign) to obtain banking services. In order to test the scientific hypotheses, we conducted a survey of clients and bank managers of 12 banks (6 state and 6 foreign). In Algeria, a separate range of financial transactions (in particular, housing lending and investment programs) is entrusted to state-owned banks only, so clients in Algeria do not leave state-owned banks, even if they also start servicing higher-quality foreign banks. The processing of the survey results showed that the key factors that determine the priorities in choosing clients of a state or foreign bank are: the reputation of the bank; tips from friends or acquaintances advice of a bank employee; accident; bank advertising (for foreign banks only). In addition, the choice of bank by a client in Algeria is influenced by behavioral and institutional factors such as religion, traditions and social customs. The survey found that just over half of the customers were satisfied with the services of state-owned banks, while $85 \%$ were completely satisfied with new banking technologies, ease of use and time savings among foreign bank clients. The main factors that determine the level of customer satisfaction with banking services are: ease of knowing cash and payment for services; highly efficient organization and simplicity of credit mechanisms; adherence to the principles of Islamic finance by some foreign banks (alternative finance, where loans and savings do not imply interest rates); more advanced banking services (mainly for foreign banks).
\end{abstract}

Keywords: bank, state bank, foreign bank, customer, competition, bank reputation, banking.

JEL classification: A12, A13.

This work is licensed under a Creative Commons Attribution 4.0 International License

Cite as: Khadidja, Z. (2020). The client's behaviour towards the bank in Algeria (Public Bank Vs Foreign Bank). Financial Markets, Institutions and Risks, 4(1), 100-108. http://doi.org/10.21272/fmir.4(1).100$\underline{108.2020}$.

(C) The Author, 2020. This article is published with open access at Sumy State University.

\section{Introduction}

In an economy where banks are facing tough and fierce competition to assert themselves in the market and to win over a scarce and demanding clientele, any dynamic bank must differentiate itself from others by applying a policy and a strategy. To this end, it implements actions to renew its product range, to better situate it, to promote its sales, to improve or maintain its brand image in the customer's mind. The bank has become aware of the new technologies, which have become the new stake of banks in general, and the Algerian bank is facing this concern integrated in its banking activity. To this end, the banking sector has become aware vis-à-vis the banking marketing and the customer's behaviour, following the changes and requirements of a customer who has become alert and demanding. So, Algeria has constantly modified its laws and has given a place to Marketing in its strategic approach, with the aim of ensuring its stability and attracting more customers.

In this paper, we will demonstrate the awareness of the customer in relation to the banking activity in general, then in relation to new technologies and the ease of operations in foreign banks. In order to remedy this, we have posed the following problem: Has the bank in Algeria become aware in relation to the customer to better position itself and assert itself in the market in front of its competitors?

Since this central questioning, several questions have come to mind, of which we set out the following:

$>$ Is the customer aware of the new technologies? 
$>$ Does the client have a preference for the two banking categories (Public or Private)?

To answer our questions, we have proposed the following suggestions, which we call hypotheses:

Hypothesis 1: The client goes to the bank that offers the most developed services.

Hypothesis 2: The Client prefers the Public bank.

Our present paper will show us whether our suggestions are correct following a demonstrative approach and a qualitative study adequate to our line of research which revolves around Banking Marketing.

\section{The Algerian banking system:}

\subsection{Legislative reminder:}

$>$ Law n ${ }^{\circ} 62-144$ establishing and fixing the statutes of the Central Bank of Algeria (BCA).

$>$ Law $n^{\circ} 80-05$, amended and supplemented, relating to the exercise of the control function by the Court of Auditors.

$>$ Law n ${ }^{\circ} 86-12$ of August 19, 1986 relating to the banking and credit regime which aims at regulating banking and financial activity. This law renews the principle according to which the banking system constitutes an instrument for the implementation of the policy set by the Government in terms of financing the national economy.

$>$ Law n ${ }^{\circ} 88-06$ of 12 January 1988 relating to the banking and credit system.

$>$ Law 90-10 of 14 April 1990 relating to money and credit.

The Algerian banking system was constituted in two main stages:

\section{First step: Establishment of a national banking system}

As early as December 1962, Algeria equipped itself with the legal and institutional instruments necessary to establish its monetary sovereignty. It creates the national currency (the Algerian dinar) and the Central Bank of Algeria (Belaid, M., 2015). Until the end of the sixties, the Algerian banking sector is still largely composed of private and foreign operators. In order to be able to finance the country's economic development, Algeria is going to work on the Algerianisation of this sector, which will gradually and exclusively become public and specialized. The nationalization of the banking sector will allow the creation of public institutions such as the Algerian Development Fund (CAD), which in 1972 became the Algerian Development Bank (BAD) and the National Savings and provident funds (CNEP). National companies such as the National Bank of Algeria (BNA), the Algerian Popular Credit (CPA) and the Algerian Eterne Bank (BEA) these take over the activities of foreign banks that have been dissolved after recovery of their assets and structures.

\section{Management and mission of the sector:}

The management of the sector is the responsibility of the Public Treasury and during these period, banks and financial institutions are instruments at the exclusive service of economic development and public enterprises (support of loss-making public enterprises and financing of their investments) (Finance Act). From 1970 and under the terms of the 1970 Finance Law, the sector became specialized; it is organized by branch of activity (Agriculture, Industry, Crafts, Hotels, Tourism, Construction, Energy, and Foreign Trade) and by company.

\section{Second stage: Liberalization of the banking system towards the private sector, both domestic and} foreign:

In 1988, the state proceeded to extensive restructuring of large public enterprises in the legal form of jointstock or limited liability companies, subject to the rules of the Commercial Code (Law n ${ }^{\circ} 88-01$ ). This new legislation enabled the creation of two new public banks, the Bank of Agriculture and Rural Development (BADR) and the Local Development Bank (BDL), which were created from the break-up of the BNA and the CPA respectively. The liberalization of the banking sector is concretized by Law 90-10 of 14 April 1990 relating to money and credit, repealing the 1986 Law on the banking system as amended and supplemented. This new law reflects the government's resolute orientation towards the market economy, which has resulted in the establishment of banks, branches and representative offices of major foreign banks (BNP Paribas, Société Générale Algérie (SGA), etc.) and foreign financial institutions (Arab Leasing Corporation, Cetelem Algeria, etc.). The main measures of this law are, the opening of the banking activity to private capital both national and foreign, and the free determination of bank interest rates by the banks without state intervention, and also the redefinition of the role of banks and the introduction of international standards in the management 
of money and credit. This law creates new autonomous bodies and establishes the principle of commerciality as a mode of bank governance.

\section{The bank in Algeria}

\subsection{Role and missions:}

The mission of the Bank of Algeria (Central Bank) is to maintain in the field of money, credit and exchange, the most favorable conditions for an orderly development of the economy (Presentation of Bank of Algeria).

The Bank of Algeria establishes the general conditions under which Algerian and foreign banks and financial institutions may be authorized to incorporate and operate in Algeria. It shall also lay down the conditions under which such authorization may be amended or withdrawn.

The Bank of Algeria shall determine all the standards that each bank must comply with at all times, in particular those concerning:

$>$ Banking management ratios;

$>$ Liquidity ratios;

$>$ The use of own funds (risks in general);

\subsection{The Algerian banking structure at present}

Algeria has given the opportunity to other foreign banks to establish themselves on the local financial market; these establishments were authorized after changes in the institutional form of the Algerian financial system, induced by the commercial and financial opening of the latter (Banking Order 01-01). Further to laws and always within the framework of the opening of the Algerian financial market and the encouragement of FDI; a regulatory text fixed the conditions of capital transfer in Algeria to finance economic activities and the repatriation of the latter and their incomes and, by the same token, consecrates the opening of the national economy. For this reason, several foreign banks have established themselves in Algeria, as shown in the following table:

Table 1. The Algerian banking structure at present.

\begin{tabular}{|c|c|c|}
\hline Foreign Banks & Date of establishment & Head Office \\
\hline Bank Al Baraka Algeria & 20 Mai 1991 & Bahrain \\
\hline Arab Banking Corporation Algeria (ABC) & 1998 & Bahrain \\
\hline Natixis Algeria & 1999 & France \\
\hline Société Générale Algérie (SGA) & 2000 & France \\
\hline Citi Bank Algeria & 2001 & USA \\
\hline Arab Bank PLC Algeria & 2002 & Jordan \\
\hline B.N.P / Paribas El Djazair & 2002 & France \\
\hline Trust Bank Algeria & 2003 & Ghana \\
\hline Housing Bank for Trad and Finance & 2003 & Jordan \\
\hline Algeria Gulf Bank (AGB) & 2004 & Abu Dhabi UAE \\
\hline Fransabank El Djazair & 2006 & France \\
\hline Calyon-Algeria & 2007 & France \\
\hline Al Salam Bank Algeria & 2008 & Bahrain \\
\hline Hong-Kong Shanghai Banking Corporation Algeria & Août 2008 & Hong Kong \\
\hline
\end{tabular}

Source: Table drawn up by the researcher according to the official websites of the various banks.

\section{Banking Marketing}

If marketing is first and foremost a state of mind intended to direct with resolution all the driving forces of banking and insurance towards customer satisfaction, they must not realize this desire to the detriment of the company's interest. In particular the two fundamental imperatives of profitability and maintaining or improving the company's image. This is why we limit ourselves to defining marketing as: "The art of satisfying its customers while pleasing its boss (profitability, quality, and image) or the art of creating value jointly for the customers and the companies" (Badoc, M., 2009).

\subsection{The marketing approach in the bank}

The marketing approach in the bank is based on the customer who is king and on the constantly changing environment. Market research, on the other hand, can be summed up as the collection and analysis of information with the aim of identifying the characteristics of a market. In the case of banks, market research 
is based on the customer's environment and culture. As the diagram below shows, the client is at the centre of the marketing approach in the bank, and the client is the key element in the competition.

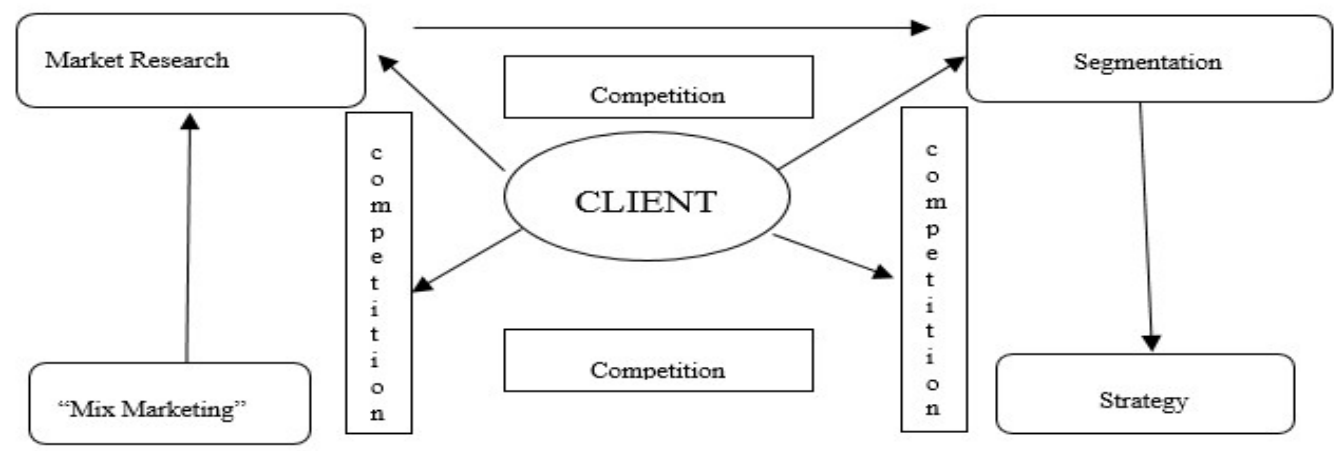

Figure 1. The Marketing Approach

Source: Michel Badoc « Le marketing bancaire et de l'assurance », Edition Revue Banque, 2e edition, Paris 209, page 16.

\subsection{Relationship Marketing}

"Relationship marketing is a policy and a set of tools designed to establish individualized and interactive relationships with customers, with a view to creating and maintaining positive and sustainable attitudes towards the company or brand" (Lendrevie, J., 2012). Relationship marketing is based on taking into account the individual in all his dimensions and in all aspects of his life, and works from the moment of circumstances. This marketing tries to grasp the complexity and relativity of behaviors in order to build marketing strategies that are clearly driven by the downstream (Jallat, F., 2001). With this in mind, banks favor an intensive and concrete marketing, connected to life, whose main objective is to transform each transaction into a relationship. The customer relationship enables a relatively precise analysis of needs and a differentiated treatment of demand. The effectiveness of relationship marketing derives from the possibilities of new actions offered by information and communication technology. Technological progress, the development of the Internet may not revolutionize the laws of commerce and economics, but it fundamentally changes the way the world does business.

\section{Methodology and research sample}

\subsection{Research methodology}

We have chosen a qualitative method, which is appropriate for our research according to the literature, to test our hypotheses (affirm or invalidate them). This qualitative method is represented by two questionnaires, the first designed for clients and the second for bank managers. However, our research work is based on an epistemological paradigm, which is both positivist and constructivist interpretive. On the other hand, our analysis is done in a scientific way, interpreted in a fine and logical manner. To argue the choice of hypotheses and to verify them afterwards. We also note that documentary techniques were used in our data collection. These have the advantage of being "objective" materials in the sense that while they raise different interpretations, they are the same for everyone, and do not change. They remain and allow for study over time (Crawitz, M., 1974).

\subsection{The Research Sample}

Two questionnaires were formulated, the first for bank clients and the second for the regional manager. Bank customers, representing a cross-section of society of different ages and functions, were our first research sample. This sample allowed us to make a selection of the banks studied. It was disseminated on the net using Google survey and published on social networks and the professional network LinkdIn. This diffusion allowed us to collect three hundred questionnaires. A sufficient sample to move on to the second phase of the research. Although, the second sample is summarized in banks chosen by the customers who answered on our first questionnaire. So, our banks are chosen based on customer selection. So, the second questionnaire was for regional bank managers.

The following graph shows us the banks apparent in the responses of the three hundred clients: 


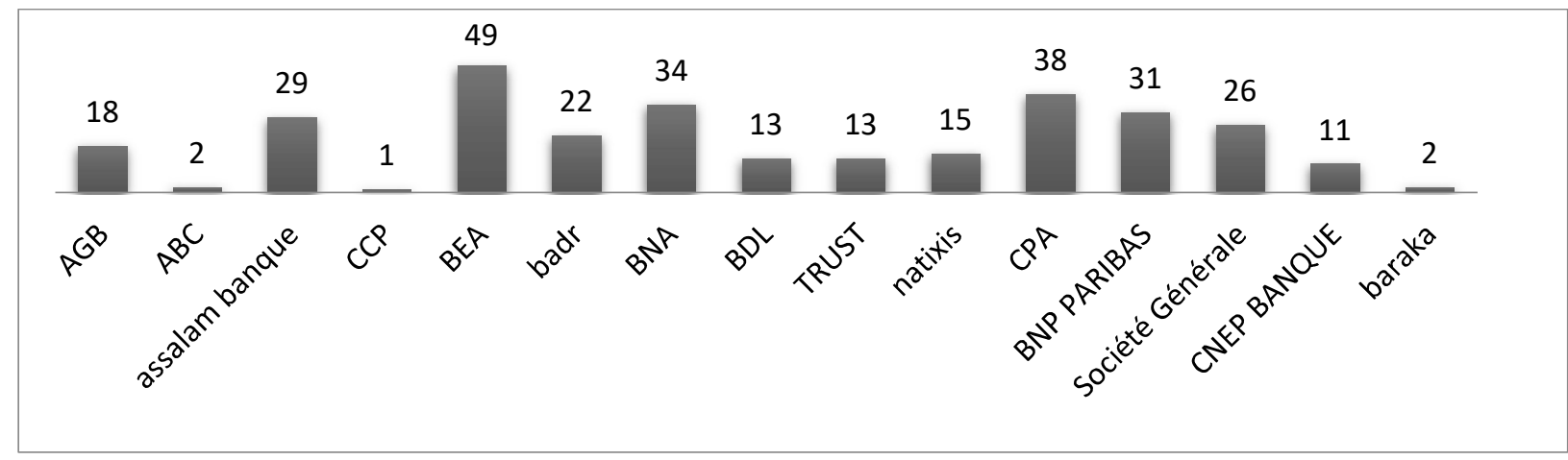

Figure 2. Breakdown of the sample by bank

Source: according to customer responses on Google Forms.

A total of 15 establishments appeared in the customer responses. Subsequently, we excluded two banks, as there was only one customer for each and also Algeria Post, of which it does not belong to the category of institutions studied (Commercial banks). After sorting the customers, we classified the customers into two categories: Customers of public banks and customers of foreign banks. This classification is demonstrated according to the following graph:

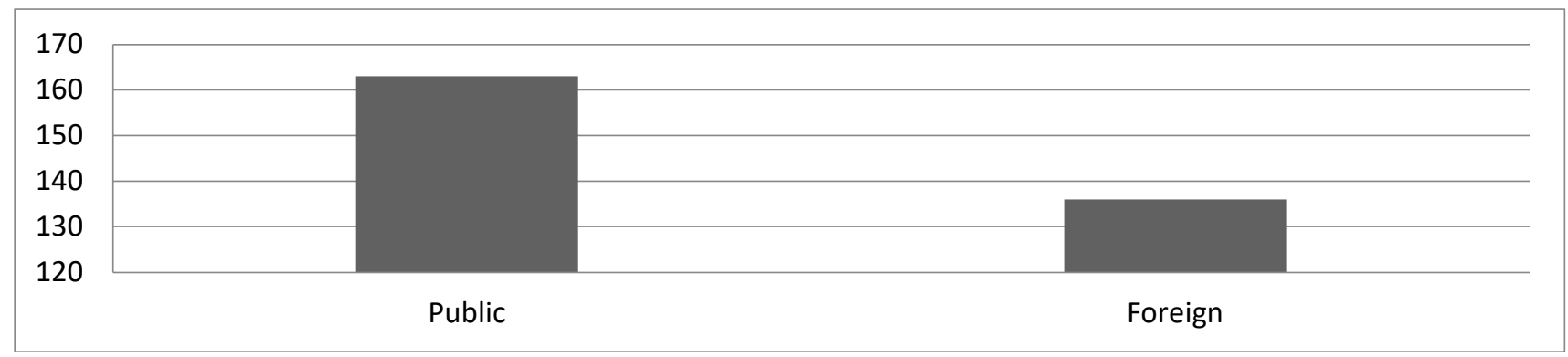

Figure 3. Breakdown of the sample (Public Bank/Private (Foreign Bank)

Source: according to customer responses on Google Forms.

\section{Search result}

\subsection{Breakdown of clients:}

In order to better identify clients, we have classified professional clients according to industry sector and individuals according to their professions as shown in the graphs below:

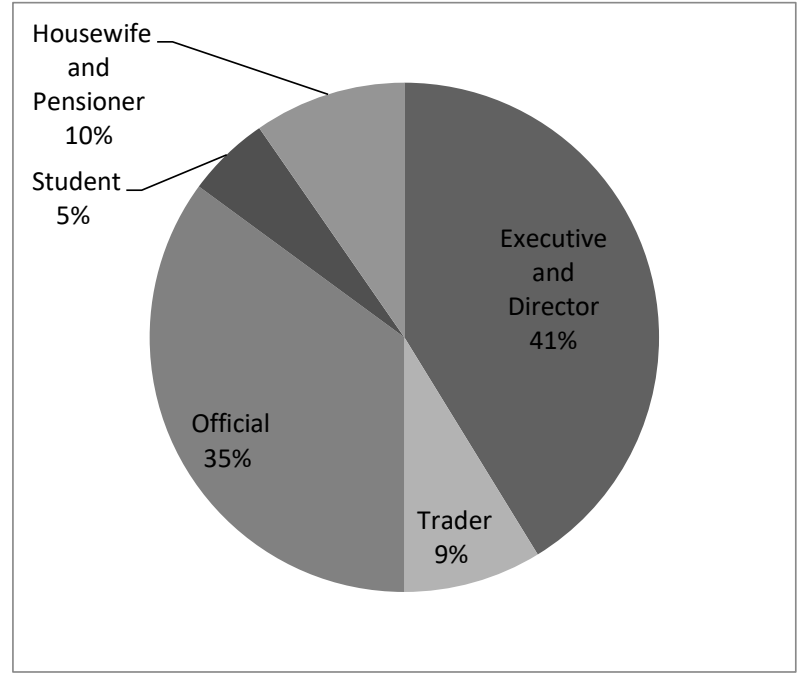

Figure 4. Distribution of individuals

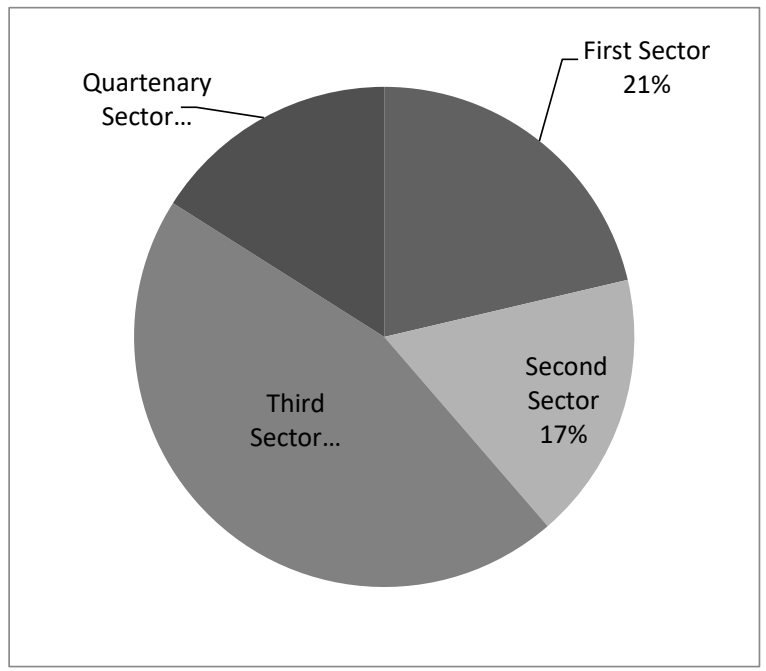

Figure 5. Breakdown of Professional by Sector

Source: according to customer responses on Google Forms. 


\subsection{Seniority of clients in both categories of banks}

According to the graphs, we indicate that the majority of professional clients come from the service sector (third sector); while individual clients are mostly executives (engineers, doctors, university teachers, managers...).

It must be said that the public bank is older than the foreign bank as we showed earlier in the theoretical framework. According to the results of the research, the clients of the public bank are older than the clients of the foreign bank, which is logical according to the history of the Algerian banking system. To this effect, the two following graphs will show us the seniority of customers in each category of banks:

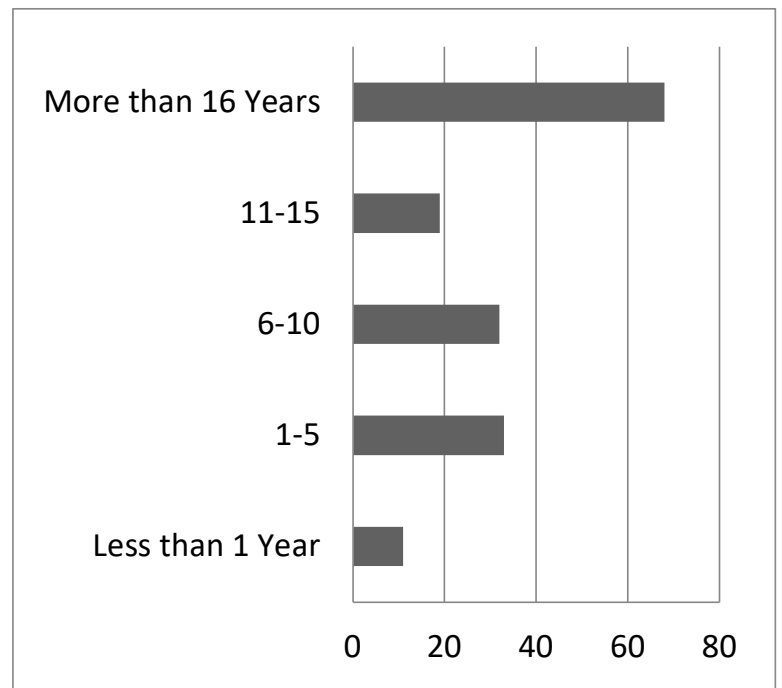

Figure 6. Seniority of client (Public Bank)

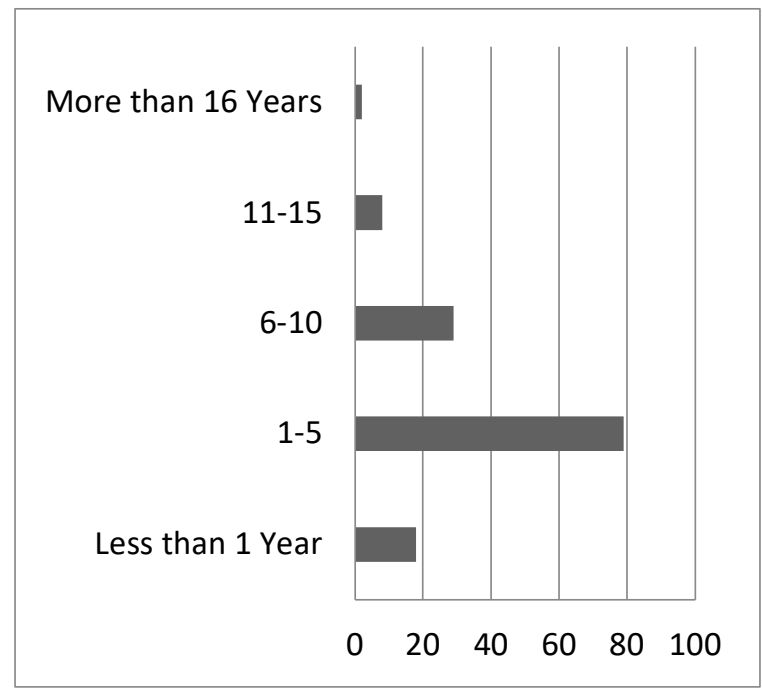

Figure 7. Seniority of client (Foreign Bank)

Source: according to customer responses on Google Forms.

\subsection{Reasons for choosing the bank and customer satisfaction}

As graphs 7 and 8 below show us, the most frequent reason is "the bank's good reputation", which is transmitted by echoes in society and especially by word of mouth. This is summarized in the reason "Through a friend or family member". Then we have other reasons such as: advertising followed by the advice of a bank employee or just chance.

Another reason and omnipresent in the public bank is "The obligation", that is the customer is obliged to go to the public bank, either by the order of his employer which is summarized in the reason "Public institution", or by the housing or investment programs offered by the state which requires domiciliation in the public bank to be able to benefit from these programs.

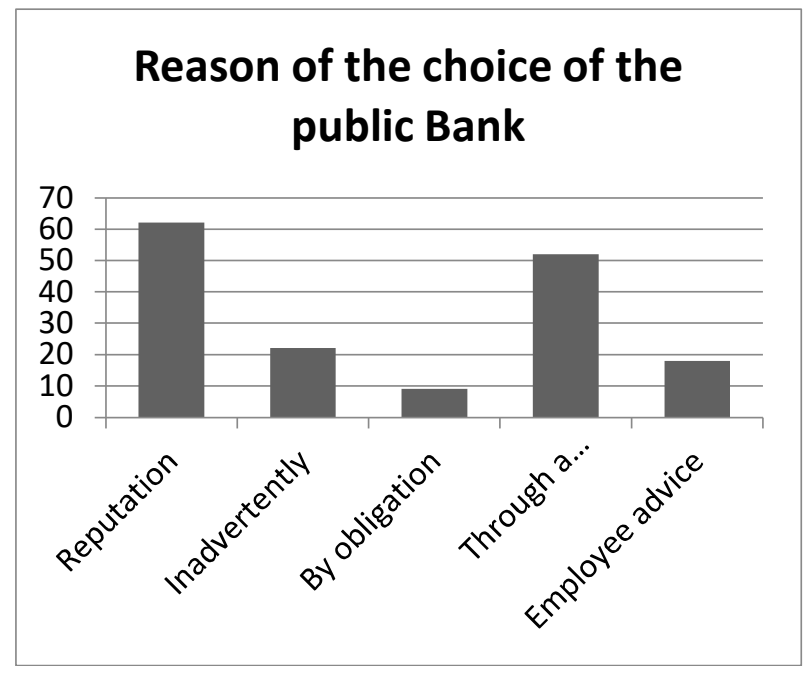

Figure 8. Reason of the choice of the Public Bank

\section{Reason of the choice of the Foreign Bank}

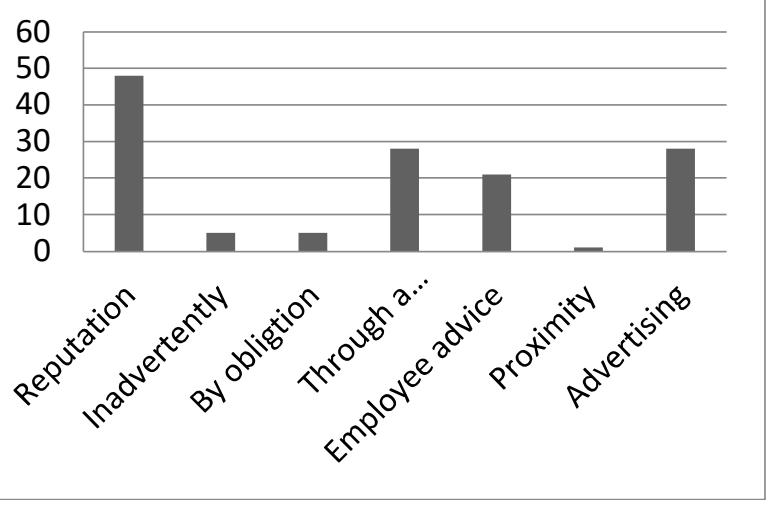

Figure 9. Reason of the choice of the Foreign Bank

Source: according to customer responses on Google Forms. 
Subsequently, we measured customer satisfaction for both categories of banks. As Graphs 9 and 10 shows, $57 \%$ of the customers of public banks are satisfied compared to $85 \%$ of the customers of foreign banks, this satisfaction is expressed by customers in relation to new technologies and ease of access to banking services, which affirms our Hypothesis H1.

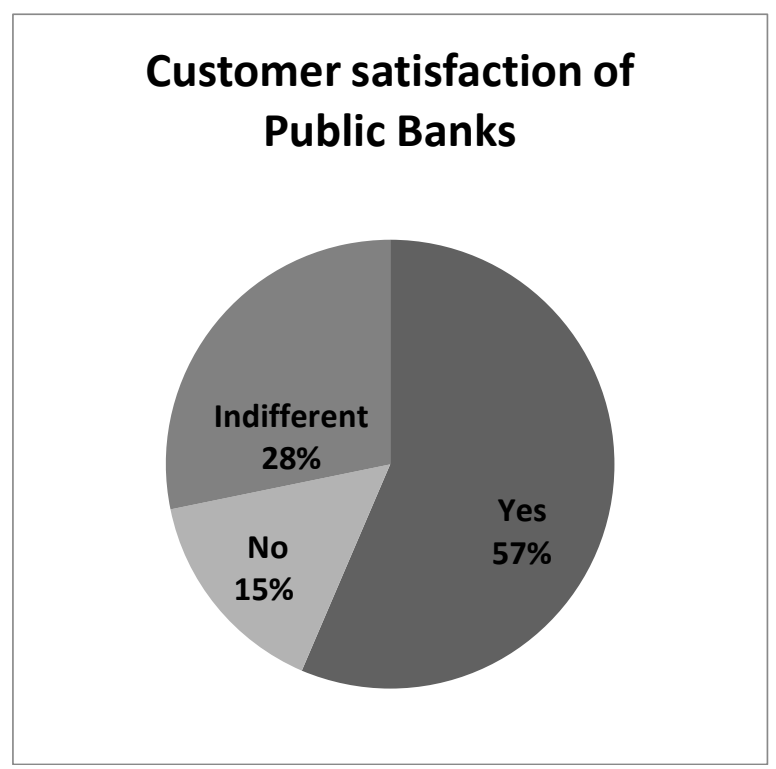

Figure 10. Customer satisfaction of Public Banks

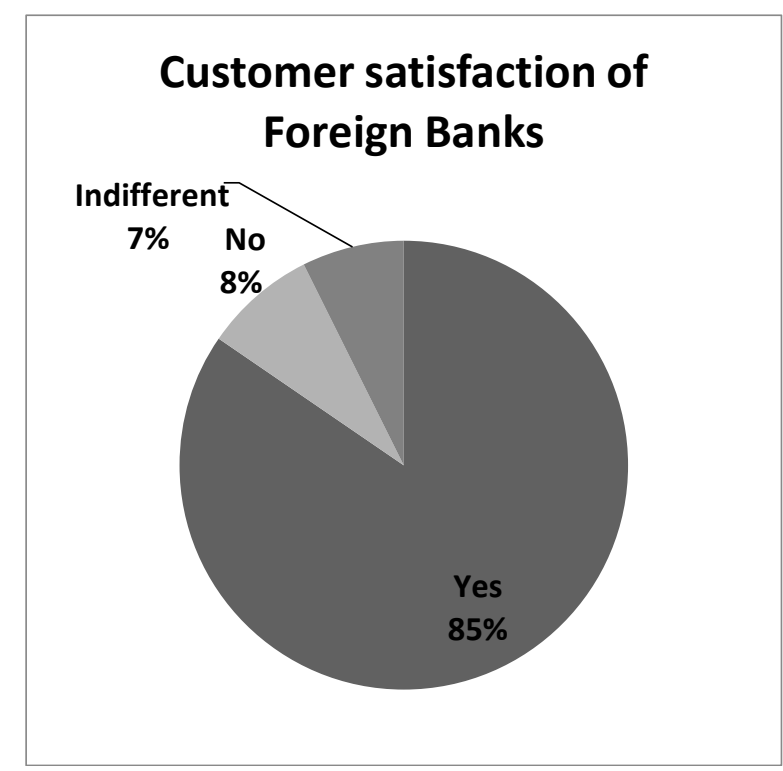

Figure 11. Customer satisfaction of Foreign Banks

Source: according to customer responses on Google Forms.

\section{Verification of hypotheses}

\subsection{The reasons why clients are satisfied}

According to the research results, the dominant reasons in both categories of banks are: The ease of withdrawal and payment followed by the good reception and the organization then the ease of credit. On the other hand, some foreign banks have a more special reason which is "Islamic finance". The latter is summed up in alternative finance in the form of credit and savings without interest rates as the Muslim religion dictates. The other reason that specifies the foreign bank is "foreign exchange operations and the bank cards related to these operations", for this reason, some clients have pointed out that they go to the foreign bank, because the latter offers more developed services than the public banks (In some public banks, foreign exchange bank cards are non-existent). This supports our hypothesis H1. And finally, "the fluidity of employees and banking services" is a reason that finds a large gap between the foreign banks with a large percentage versus a small percentage in the public bank.

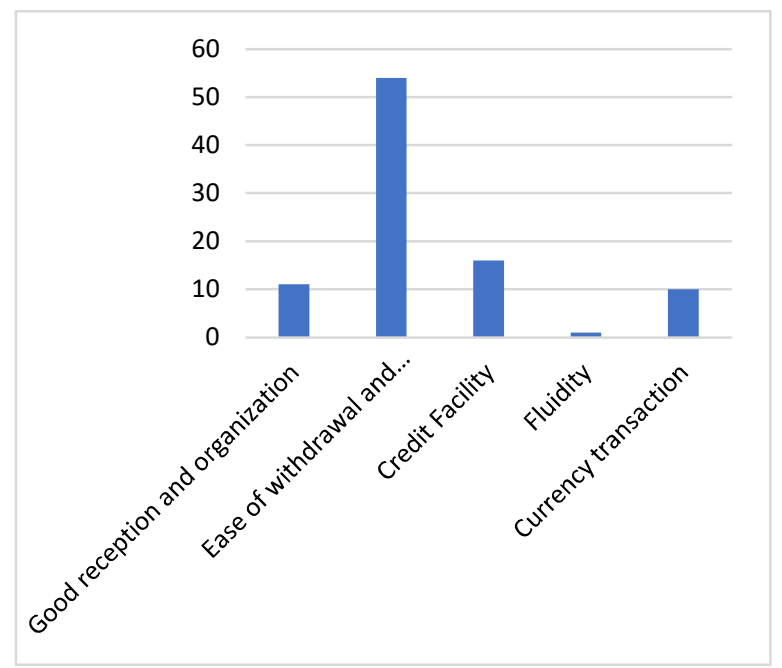

Figure 12. Reason of satisfaction of the Public Customer Banks Banks

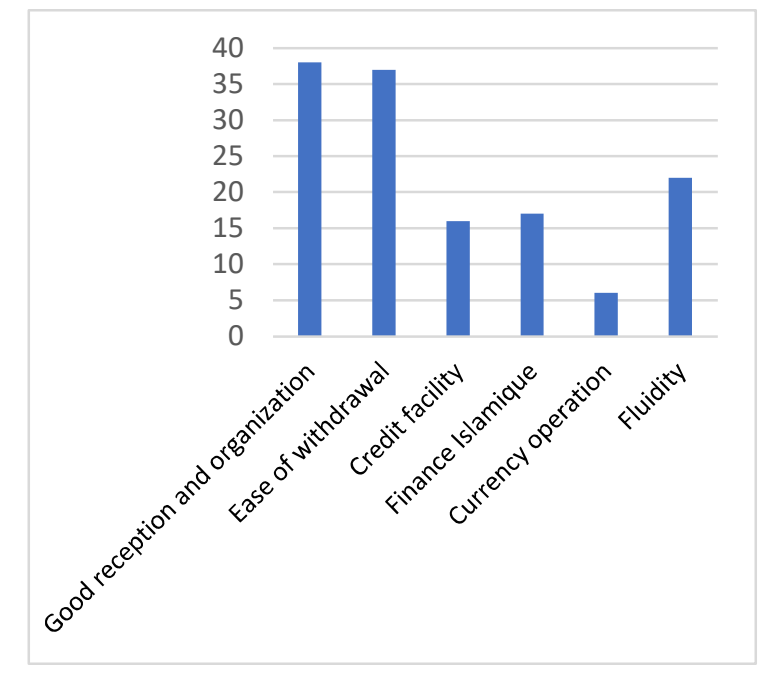

Figure 13. Reason of satisfaction of the Foreign Customer 


\subsection{The reasons for customer loyalty}

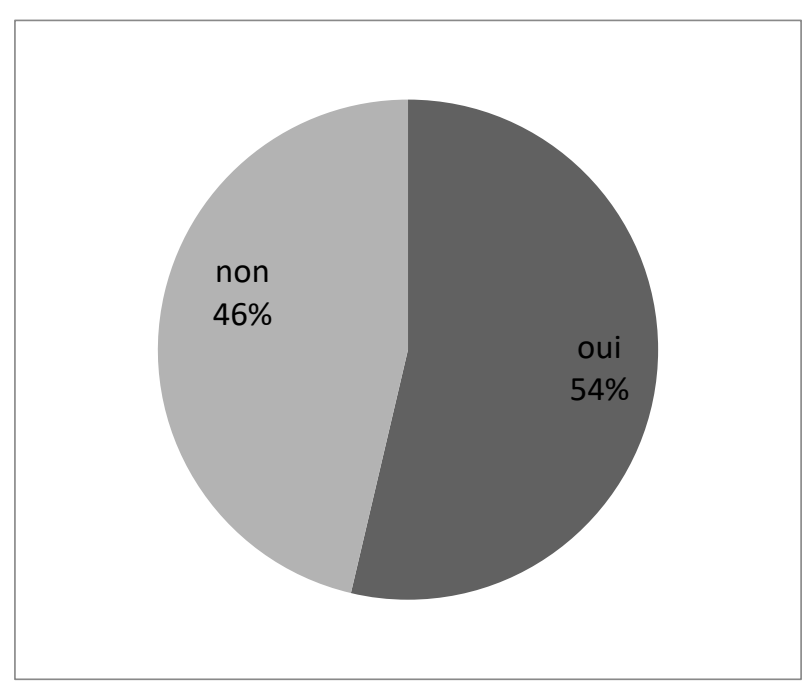

Figure 13. Breakdown of the Foreign bank Client,

who have been Client in Public Bank

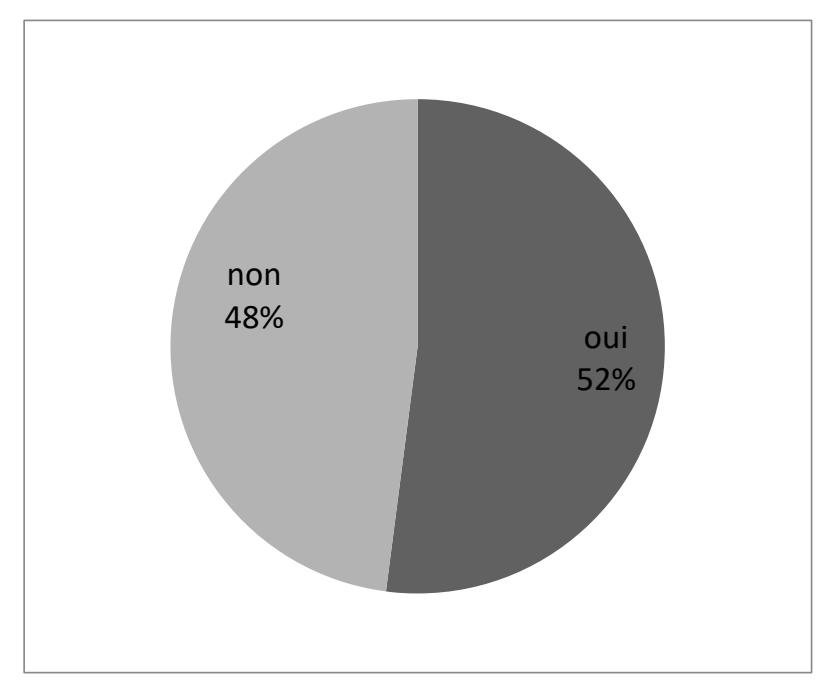

Figure 14. Client of Foreign Bank, who keep their accounts in Public Bank

Source: according to customer responses on Google Forms.

According to graph 13 , we note that $54 \%$ of the clients of foreign banks were clients of public banks. This change in banks is reflected according to customer responses by the application of new technologies and the good reception in most foreign banks, which is missing in public banking. This answer also affirms the H1 hypothesis.

In Revenge and as explained in graph $14,52 \%$ of the customers of foreign banks did not leave the public bank and kept their savings operations at the level of the latter. So, the customers have a banking preference which affirms our hypothesis $\mathrm{H} 2$.

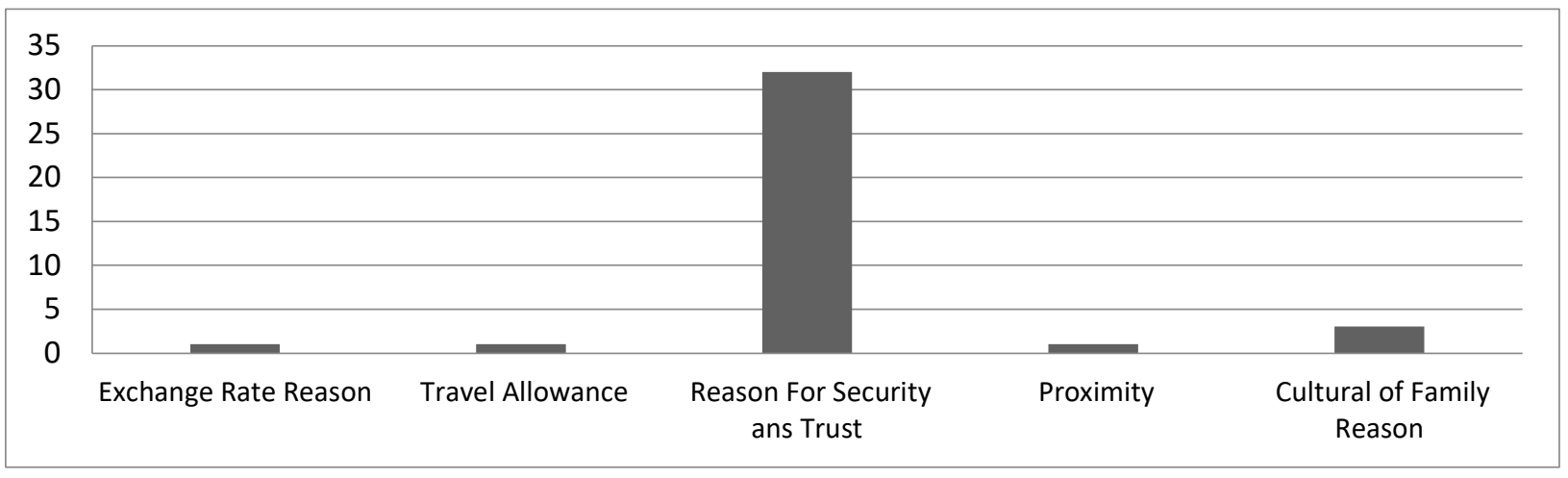

Figure 15. Reason of client loyalty to Public Bank's compared to Foreign Bank's

Source: according to customer responses on Google Forms.

In order to better understand the reasons for the loyalty of foreign bank customers, who keep their accounts in their former public banks, we asked these customers, whose dominant reason is "Reason of security and trust", followed by "Family and cultural reason".

To this end and as shown in (Chart 15), clients trust the public bank even if it does not offer the best services, which affirms our hypothesis $\mathrm{H} 2$.

\section{Conclusion}

The bank is a complex field of investigation due to the nature of its activity and its intangible products linked to an uncertain environment. Moreover, the client and the center of the banking activity, the latter influenced by a set of elements including society and culture, which play a primordial role in the behaviour of the individual. For this reason, the bank must remain vigilant and use the best means to attract the maximum number of customers. It is also stressed that the bank's main reason for doing business is to make the most profit. Therefore, this combination of clients and profits must be treated very seriously. This explains the 
emergence of new techniques for processing information and the introduction of science in data processing. In this respect, our research center was the customer; we wanted to see whether customer satisfaction represents a competitive advantage for the bank. And that was our central questioning.

Subsequently, we found that some customers are aware of the choices made by their banks, translated into specific reasons related to development and technology. On the other hand, customers do not leave through public banks despite their emigration to foreign banks, which explains why the customer in Algeria does not trust the foreign bank even if it offers the best services. It should also be noted that public banking is consolidated by the state, as certain operations are entrusted to these banks, such as housing and certain investment programs. And finally, the customer in Algeria is influenced by a number of factors, among which we mention: religion, traditions and customs of the society.

\section{References}

1. Badoc, M. (2009). Le marketing bancaire et de l'assurance. [Banking and insurance marketing]. Revue Banque Edition, 2nd Edition, Paris, 14-15. Available at: https://publications.banque-france.fr/sites/default/ files/medias/documents/fsr21 web.pdf

2. Belaid, Mc. (2015). Collectif EPBI "Comprendre la banque". [Collective EPBI "Understanding the bank]. International Blue Pages Edition, Algeria, 15-18. https://www.embassyfreight.co.uk/news/algeria-newregulations/

3. Banking Order 01-01 of 27 February 2001 amending and supplementing Banking Act 90-10 of 14 April 1990 on money and credit. Available at: https://www.bis.org/review/r150127b.pdf, Accessed 15 March 2020.

4. Crawitz, M. (1974). Methods of Social Sciences, DALLOZ edition, Paris, 87. Available at: https://journals.openedition.org/remmm/10032

5. Jallat. F. (2001). A la reconquête du client. [A customer reconquest]. Village Mondial Edition, Paris, 42. Available at: https://www.pearson.ch/HigherEducation//EAN/9782326001800/Gestion-de-la-relationclient-5e-edition

6. Lendrevie, J., Levy, J. (2012). Mercator, Dunod Edition, Paris, 55. Available at: https://books.google.com.ua/books?id=7tLRDgAAQBAJ\&pg=PA195\&lpg=PA195\&dq=Lendrevie, + J., +

Levy, $+\mathrm{J} .+(2012) .+$ Mercator, + Dunod + Edition,+ Paris,,$+55 . \&$ source $=$ bl\&ots $=$ K6arm q $\quad$ FBn\&sig $=A C f$ U3U0gl7eGRPzpLAolhgRvhPIMIuh yw\&hl=ru\&sa=X\&ved=2ahUKEwjIOPWHuc7oAhWEposKHagYD wIQ6AEwCnoECAsQLQ

7. Finance Act, year 1970 and 1970, December. Available at: https://www.legifrance.gouv.fr/affichTexte.do? cidTexte=JORFTEXT000000693424\&categorieLien=id, Accessed 15 March 2020.

8. Law n ${ }^{\circ} 88-01$ of 12 January 1988 relating to the orientation of economic public enterprises. Available at: http://link.library.ibfd.org/portal/Loi-No.-88-01-du-12-janvier-1988-portant-loi/gEnMQJAM3XM/, Accessed 13 March 2020.

9. Presentation of Bank of Algeria. (2018). Available at: http://www.bank-of-algeria.dz/html/present.htm 